\title{
Regulating the rooting process of rose softwood cuttings by foliar citric and malic acid spray on stock plants
}

\author{
Noushin Ghazijahani ${ }^{1}$ Ebrahim Hadavi ${ }^{2 *}$, Chul Hwan Hwang ${ }^{3}$, \\ Byoung Ryong Jeong ${ }^{3}$ \\ ${ }^{1}$ Department of Microbiology \\ ${ }^{2}$ Department of Horticultural Sciences \\ Karaj Branch, Islamic Azad University \\ Karaj, Iran \\ ${ }^{3}$ Department of Horticulture, Division of Applied Life Sciences \\ Graduate School, Gyeongsang National University \\ Jinju 660-701, Republic of Korea
}

\begin{abstract}
We evaluated the effects of spraying different concentrations of citric and malic acids on stock plants in the greenhouse prior to the propagation and rooting of rose (Rosa $\times$ hybrida 'Love Letter') cuttings. Malic and citric acids (3, 6 and $9 \mathrm{mM}$ ) were sprayed several times at 14-day intervals on rose plants in a commercial cut flower producing greenhouse. Single-node cuttings taken from flowering stems were rooted under misty conditions, and the rooting parameters including root count and dry root weight were measured. A distinct change was observed in rooting features in response to the applied organic acids. Malic acid significantly enhanced rooting at the intermediate concentration while retarding it at both the higher and lower concentrations. On the other hand, the effect of citric acid was best at the highest concentration applied. We conclude that in softwood cuttings taken from rose plants these organic acids can act as a potential alternative to the currently applied methods of promoting rooting.
\end{abstract}

Key words: bud-break, foliar spray, organic acids, rooting quality, Rosa $\times$ hybrida

\section{INTRODUCTION}

In 2016, the global import of cut flowers (both fresh and dry; HS:0603) reached 6.5 billion USD. Cut roses rank first, with a total world import of 2.2 billion USD. They are followed by chrysanthemums and carnations, with 775 and 407 million USD, respectively (UN Comtrade 2016).

Rose cuttings are treated with synthetic auxins (such as IBA and NAA) to promote adventitious root formation. However, the applied auxins inhibit bud development on the cuttings (de Vries and Dubois 1988, Sun and Bassuk 1993). Despite adequate rooting, high concentrations of auxins may prevent shoot growth or cause young shoots to abscise after bud-break.

Spray treatment of stock plants with auxin prior to collecting cuttings has been tried. Stoutemyer and O'Rourke (1945) sprayed stock plants of several woody ornamentals with selected concentrations of the auxin, 2,4,5-trichlorophenoxyacetic acid (TCPA), and its sodium salt. The results suggested that cuttings taken from plants treated with foliar-

\footnotetext{
*Corresponding author. 
applied TCPA show essentially the same rooting responses as cuttings treated with auxins.

Endogenous organic acids are both the source of the carbon skeleton and energy for cells, and are used in the respiratory cycle and other biochemical pathways (da Silva 2003). Malic acid (MA) is metabolized by the action of malic enzyme (EC 1.1.1.39) in plant mitochondria (Day and Hanson 1977). Malate is a common reserve anion in plant vacuoles that acts as a counter-ion to $\mathrm{K}$ and Ca (Ting 1981), particularly in nitrate-dependent plants (Osmond and Laties 1969). Citrate and malate exuded by the roots of calcicole plants (plants growing in alkaline soils) enable them to extract $\mathrm{P}$ and Fe from such soils (Lopez-Bucio and Nieto-Jacobo 2000). Citric acid (CA) has been used as a foliar spray, alone or in combination with $\mathrm{Fe}$ sources, to help plants recover from iron chlorosis (Tagliavini et al. 2000, Abadía et al. 2002, ÁlvarezFernández et al. 2004, Eidyan et al. 2014). The use of CA alone or in combinations with salicylic acid (SA) and MA increased the essential oil production in sweet basil (Jaafari and Hadavi 2012a) and dill (Jaafari and Hadavi 2012b). Promising effects on some physiological parameters were obtained by foliar application of CA in tuberose (Eidyan et al. 2014), Lilium (Darandeh and Hadavi 2012), and bean (El-Tohamy et al. 2013). It was shown that the essential oil composition changed in response to different combinations of foliar-applied CA and MA (Jaafari et al. 2015). Foliar pre-harvest application of the combinations of SA and CA in soilless culture increased the vase life of cut rose flowers (Hajreza et al. 2013). A recent study on sweet basil revealed that the combination of $1 \mathrm{mM}$ SA with $7 \mathrm{mM} \mathrm{CA}$ was superior to others in improving many physiological traits and yield (Mirzajani et al. 2015). It was proposed that the root-soil interaction was affected by such foliar sprays, leading to an increase in nutrient absorption by the roots (Jaafari and Hadavi 2012b).

Due to the physiological changes and changes in the carbon partitioning pattern in sprayed plants, we had expected some effect on their rooting as well, which is an important feature in rose. Therefore, in the present experiment, the possible regulation effects of spray treatments with the above-mentioned organic acids on the subsequent rooting parameters of herbaceous cuttings were investigated.

\section{MATERIAL AND METHODS}

This study was conducted in the experimental greenhouse of the Horticulture Department at
Gyeongsang National University, Jinju, South Korea, during the autumn season of 2013. The rose (Rosa $\times$ hybrida 'Love Letter') plants were managed in a commercial hydroponic cut rose production greenhouse near Gimhea, Korea. Starting on $17^{\text {th }}$ September, the plants were sprayed biweekly a total of 6 times with 8 treatments including CA $(3,6$ or $9 \mathrm{mM})$ and $\mathrm{MA}(3,6$ or $9 \mathrm{mM})$. Two control treatments were used: one sprayed with distilled water (DW) and the other left unsprayed (nospray). A few drops of Tween 20 were added to all the sprays as the surfactant. The experiment was conducted in a completely randomized design with three replications with 10 stock plants in each. The management of plants and the cut flower harvest were conducted in a conventional way. Unopened flowers were cut off and transferred to the experimental greenhouse in Gyeongsang National University, Jinju, Korea. Single-node cuttings were taken from the middle part of the flower stems with five leaflets, from which the terminal leaflet was removed. Twelve cuttings were prepared from each replication and cultured in rockwool cubes $(5 \times 5$ $\mathrm{cm})$. They were stored under continuous mist for 3 weeks, and subsequently under an intermittent mist for another 3 weeks $\left(23 \pm 1^{\circ} \mathrm{C}\right)$. The rooting parameters including the mean root count, rooting rate and greatest root length, were recorded. Then the cuttings were dried in an oven at $70^{\circ} \mathrm{C}$ for 72 hours and the dry weights of the roots and shoots were measured. The collected data was analyzed for statistical significance with the SPSS (ver. 16.0, SPSS Inc., Chicago, IL, USA). Furthermore, a specific procedure of SPSS (automatic linear modelling) was used in order to forecast and model the components of root dry weight. The data preparation was automatic and the 'model selection method' used was Forward Stepwise. The accuracy of the regression model was $79.6 \%$, which represents the adjusted $R^{2}$ multiplied by 100 .

\section{RESULTS AND DISCUSSION}

\section{Rooting rate}

The rooting rate was between 91.3 to $100.0 \%$ in all the treatments except for $3 \mathrm{mM}$ MA with a significantly lower rooting rate of $72.3 \%$ (Tab. 1, Fig. 1). This indicated that the applied rooting technique was an appropriate one. This is comparable to the report by Pivetta et al. (1997), who reported a $98 \%$ rooting rate with an easy to root variety. Earlier reports (Hwang et al. 2015) were 
Table 1. The effect of spray treatments on rooting parameters

\begin{tabular}{lcccccc}
\hline Treatment & $\begin{array}{c}\text { Cutting fresh } \\
\text { weight } \\
(\mathrm{g})\end{array}$ & $\begin{array}{c}\text { Root } \\
\text { count }\end{array}$ & $\begin{array}{c}\text { Greatest root } \\
\text { length } \\
(\mathrm{mm})\end{array}$ & $\begin{array}{c}\text { Shoot bud-break } \\
\text { rate } \\
(\%)\end{array}$ & $\begin{array}{c}\text { Root dry weight } \\
\text { (mg per cutting) }\end{array}$ & $\begin{array}{c}\text { Rooting } \\
\text { rate }\end{array}$ \\
\hline No Spray & $2.8 \mathrm{a} \mathrm{a}^{*}$ & $6.8 \mathrm{~b}$ & $5.2 \mathrm{ab}$ & $64 \mathrm{ab}$ & $28.3 \mathrm{~b}-\mathrm{d}$ & $100.0 \mathrm{a}$ \\
DW & $2.7 \mathrm{a}$ & $4.9 \mathrm{c}$ & $3.9 \mathrm{ab}$ & $61 \mathrm{ab}$ & $23.9 \mathrm{c}-\mathrm{e}$ & $92.0 \mathrm{a}$ \\
CA $3 \mathrm{mM}$ & $2.7 \mathrm{a}$ & $7.9 \mathrm{ab}$ & $5.6 \mathrm{ab}$ & $53 \mathrm{ab}$ & $42.7 \mathrm{ab}$ & $94.6 \mathrm{a}$ \\
CA $6 \mathrm{mM}$ & $2.8 \mathrm{a}$ & $4.7 \mathrm{c}$ & $4.6 \mathrm{ab}$ & $50 \mathrm{ab}$ & $21.9 \mathrm{de}$ & $91.3 \mathrm{a}$ \\
CA 9 mM & $2.8 \mathrm{a}$ & $7.0 \mathrm{~b}$ & $6.2 \mathrm{a}$ & $83 \mathrm{a}$ & $37.9 \mathrm{a}-\mathrm{c}$ & $100.0 \mathrm{a}$ \\
MA 3 mM & $2.3 \mathrm{a}$ & $1.5 \mathrm{~d}$ & $3.2 \mathrm{~b}$ & $35 \mathrm{~b}$ & $13.5 \mathrm{e}$ & $72.3 \mathrm{~b}$ \\
MA $6 \mathrm{mM}$ & $2.8 \mathrm{a}$ & $8.5 \mathrm{a}$ & $5.2 \mathrm{ab}$ & $50 \mathrm{ab}$ & $44.9 \mathrm{a}$ & $97.3 \mathrm{a}$ \\
MA $9 \mathrm{mM}$ & $2.7 \mathrm{a}$ & $7.1 \mathrm{~b}$ & $5.3 \mathrm{ab}$ & $56 \mathrm{ab}$ & $36.5 \mathrm{a}-\mathrm{c}$ & $100.0 \mathrm{a}$ \\
\hline
\end{tabular}

*Means with the same letters are not statistically different based on Duncan's test $(p<0.05)$. DW - distilled water, CA - citric acid, MA - malic acid

indicative of a difficult-to-root habit for this variety, whereas we obtained a more acceptable rooting rate in our experiment. However, the rooting rate alone may be misleading because the rooted cuttings may not all go through the subsequent steps of acclimatization equally well due to differences in rooting quality.

\section{Cutting fresh weight}

As seen in Table 1, there was no difference among the treatments in terms of the fresh weight of cuttings.

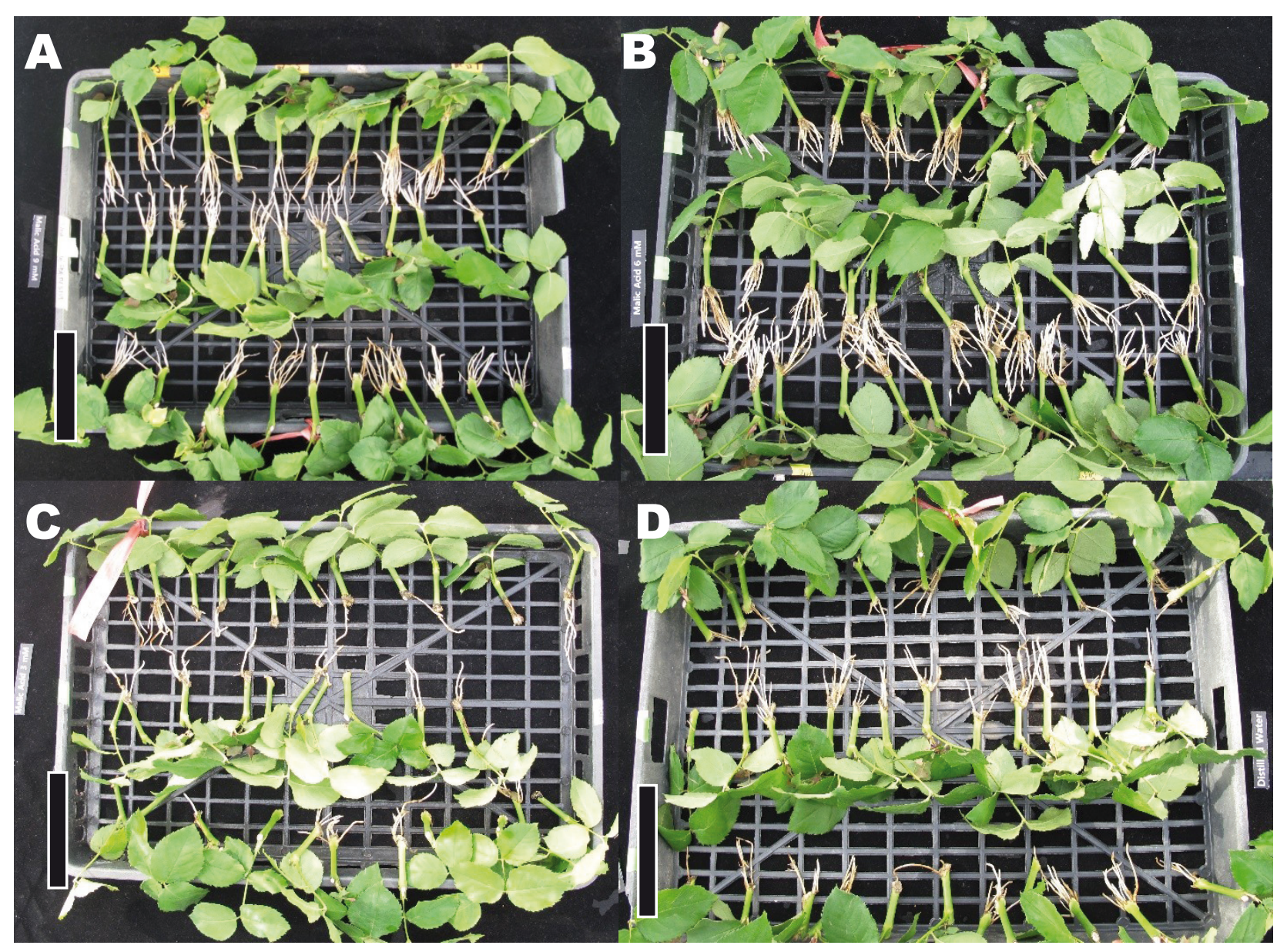

Figure 1. The rooting response to concentrations of foliar malic acid (MA) sprays on stock plants. (A) $9 \mathrm{mM}$, (B) $6 \mathrm{mM}$, (C) $3 \mathrm{mM}$ and (D) $0 \mathrm{mM}$ or distilled water. The negative effect of $3 \mathrm{mM}$ MA on root count is evident in (C), while application of $6 \mathrm{mM}(\mathrm{B})$ increased this parameter. Root count was again reduced by increasing MA concentration to $9 \mathrm{mM}$ (A), which was then on a par with the control treatment sprayed with distilled water (D) $(1 \mathrm{bar}=10 \mathrm{~cm})$ 


\section{Greatest root length}

There was no difference in root length among the treatments. It seems that following initiation the roots continued to grow more or less evenly (Tab. 1).

\section{Shoot bud-break}

As seen in Table 1, the highest and lowest budbreak rates were observed in $9 \mathrm{mM} \mathrm{CA}$ and $3 \mathrm{mM}$ MA, respectively, although neither result was considered statistically different from any of the control treatments. It seems that MA at the $3 \mathrm{mM}$ level had a profound effect on the cuttings by reducing both their root count and shoot break-out rate. Auxin-induced ethylene synthesis is primarily responsible for the bud-break inhibition of auxintreated cuttings (Sun and Bassuk 1993). Therefore, our results could indicate that the applied organic acids affected the internal PGR balance of the cuttings, leading to an altered bud-break pattern.

\section{Root count}

This is an important index for assessing the quality of rooting. The cuttings taken from the plants that had been sprayed with $6 \mathrm{mM}$ MA had the highest mean root count per cutting (8.5), which was significantly higher than for both control treatments. CA at $3 \mathrm{mM}$ and $\mathrm{MA}$ at $9 \mathrm{mM}$ gave the next best results, showing a significant difference relative to the DW treatment, while lacking such a difference relative to the no-spray treatment. The lowest root count (1.5) was recorded for $3 \mathrm{mM} \mathrm{MA}$, which was significantly lower than for both control treatments (Tab. 1).

\section{Root dry weight}

A relatively large variation was noticed in this trait when compared with the previous parameters. The highest root dry weight was recorded for $6 \mathrm{mM} \mathrm{MA}$, which was proven to be significantly higher than the values for both control treatments. On the other hand, the lowest root dry weight was obtained after spraying with $3 \mathrm{mM} \mathrm{MA}$, which was significantly lower than the result for the no-spray treatment, but not the DW treatment. The pattern of response to MA concentrations was similar to that observed for root count. The applied linear regression modelling suggests that root count is the key predictor of root dry weight $(p<0.01)$.

The mechanism of the observed responses to organic acids remains unclear. $\mathrm{Hu}$ et al. (2016) found that external application of CA induced the accumulation of endogenous $\mathrm{CA}$ in leaf tissue, which coincided with an alleviation of the detrimental effects of heat stress on tall fescue. Changes in the pattern of carbohydrate distribution in the plant (Eidyan et al. 2014, Talebi et al. 2014, Mirzajani et al. 2015) may have played a role.

\section{CONCLUSIONS}

In our experiment, except for the treatment with $3 \mathrm{mM}$ MA, the differences in rooting percentage were not very pronounced. MA at $6 \mathrm{mM}$ caused both the highest root count and root dry weight, while $9 \mathrm{mM}$ CA increased the bud-break rate significantly.

Our results show for the first time that foliarapplied organic acids could have a profound effect on the rooting process. The dose-dependent growthregulating effect of MA at lower concentrations $(3 \mathrm{mM})$ is considered interesting. We conclude that using organic acid sprays could be regarded as an alternative strategy to increase the root count of single-node cuttings of rose.

\section{FUNDING}

The work was co-supported by IAU and GNU.

\section{AUTHOR CONTRIBUTIONS}

N.G. and E.H. - planned and designed the research; N.G, B.J. and C.H. - performed the experiments, conducted fieldwork; E.H. - analyzed the data and prepared the manuscript.

\section{CONFLICT OF INTEREST}

Authors declare no conflict of interest.

\section{REFERENCES}

Abadía J., Lopez-Millan A.-F., Rombola A., Abadía A., 2002. Organic acids and Fe deficiency: a review. Plant Soil 241: 75-86.

Álvarez-Fernández A., García-Laviña P., Fidalgo C., Abadía J., Abadía A., 2004. Foliar fertilization to control iron chlorosis in pear (Pyrus communis L.) trees. Plant Soil 263: 5-15.

DA Silva J.A.T., 2003. The cut flower: postharvest considerations. J. Biol. Sci. 3: 406-442.

DARANDEH N., HADAVi E., 2012. Effect of pre-harvest foliar application of citric acid and malic acid on chlorophyll content and post-harvest vase life of Lilium cv. Brunello. Front. Plant Sci. 2: 106.

Day D.A., Hanson J.B., 1977. Pyruvate and malate transport and oxidation in corn mitochondria. Plant Physiol. 59: 630-635.

DE Vries D., Dubois L.A., 1988. The effect of BAP and IBA on sprouting and adventitious root formation of 
'Amanda' rose single-node softwood cuttings. Sci. Hortic. 34 :115-121.

Eidyan B., Hadavi E., Moalemi N., 2014. Pre-harvest foliar application of iron sulfate and citric acid combined with urea fertigation affects growth and vase life of tuberose (Polianthes tuberosa L.) 'PorPar'. Hortic. Environ. Biotechnol. 55: 9-13.

El-Tohamy W., El-Abagy H., Badr M., Gruda N., 2013. Drought tolerance and water status of bean plants (Phaseolus vulgaris L.) as affected by citric acid application. J. Appl. Bot. Food Qual. 86: 212216.

Hajreza M., Hadavi E., Zeynanlou A., Mirzapour M., NAeini M., 2013. Effect of different levels of citric acid and salicylic acid at pre-harvesting stage on vase-life of rose (Rosa hybrida L.) cut flower. J. Sci. Technol. Greenhouse Culture 4: 99-109.

Hu L., Zhang Z., Xiang Z., Yang Z., 2016. Exogenous application of citric acid ameliorates the adverse effect of heat stress in tall fescue (Lolium arundinaceum). Front. Plant Sci. 7: 179.

Hwang C.H., Dal Jin Sim J.E.P., Park Y.G., Jeong B.R., 2015. Rooting and growth affected by physiological condition of the stock plant for cutting propagation of roses. Propag. Ornam. Plants 15: 95-100.

JAAFARI N., HADAvi E., 2012a. Growth and essential oil yield of basil (Ocimum basilicum L.) as affected by foliar spray of citric acid and salicylic acid. Z. Arznei Gewurzpfl. 17: 80-83.

JAAFARI N., Hadavi E., 2012b. Growth and essential oil yield of dill (Anethum graveolens) as affected by foliar sprays of citric acid and malic acid. Acta Hort. 955: 287-290.

JaAfari N., Mirzaei H.H., Hasanloo T., Hadavi E., 2015. Manipulating essential oil composition of dill (Anethum graveolens L.) by using preharvest foliar sprays of citric acid and malic acid. J. Essent. Oil Bear. Plants 18: 556-560.

Lopez-Bucio J., NiETO-JACOBO M.I., 2000. Organic acid metabolism in plants: from adaptive physiology to transgenic varieties for cultivation in extreme soils. Plant Sci. 160: 1-13.

Mirzajani Z., Hadavi E., Kashi A., 2015. Changes in the essential oil content and selected traits of sweet basil (Ocimum basilicum L.) as induced by foliar sprays of citric acid and salicylic acid. Ind. Crops Prod. 76: 269-274.

Osmond C., Laties G.G., 1969. Compartmentation of malate in relation to ion absorption in beet. Plant Physiol. 44: 7-14.

Pivetta K., Pereira F., Banzatto D., Graziano T., 1997. Effect of type of cuttings and indolbutyric acid on the rooting of rose (Rosa sp. 'Red Sucess') leafy cuttings during two seasons. Acta Hort. 482: 333338.

Stoutemyer V., O'rourke F., 1945. Rooting of cuttings from plants sprayed with growth regulating substances. Proc. Am. Soc. Hortic. Sci. 46: 407-411.

Sun W.-Q., Bassuk N.L., 1993. Auxin-induced ethylene synthesis during rooting and inhibition of budbreak of 'Royalty' Rose Cuttings. J. Am. Soc. Hort. Sci. 118: 638-643.

Tagliavini M., Abadía J., Rombolà A., Abadía A., Tsipouridis C., Marangoni B., 2000. Agronomic means for the control of iron deficiency chlorosis in deciduous fruit trees. J. Plant Nutr. 23: 2007-2022.

TAlebi M., HAdavi E., JAAFARi N., 2014. Foliar sprays of citric acid and malic acid modify growth, flowering, and root to shoot ratio of gazania (Gazania rigens L.): A comparative analysis by ANOVA and structural equations modeling. Adv. Agric. 2014: 147278.

TING I., 1981. Towards a model for malate accumulation in plant tissues. Plant Sci. Lett. 21: 215-221.

UN Comtrade, 2016. The United Nations Commodity Trade Statistics Database (UN Comtrade). Available online at http://comtrade.un.org; cited on 4 July 2017.

Received March 10, 2017; accepted June 28, 2017 